\title{
SUFFERING FOR THE LOVE OF GOD: ADAM, JOB, THEOTOKOS AND CHRIST*
}

\section{SUFRIENDO POR EL AMOR DE DIOS: ADÁN, JOB, THEOTOKOS Y CRISTO}

KATEŘINA KUTARŇOVÁ

University of South Bohemia

Recibido: 04/07/2018

Aceptado: 26/09/2018

\section{ABSTRACT}

The paper attempts to see the question of the ,suffering of the just' in the theological perspective of the Book of Job, seeing Job in contrast to the First Man. Furthermore, it explores the possibility of understanding Job not only as a typos of Christ but also as the typos of the Most Holy Mother of God. Beside the biblical texts themselves the essay is strongly influenced by the though of Thomas Aquinas.

Keywords: Suffering of the Just, Adam, Job, Christ, Theotokos, Aquinas.

\section{RESUMEN}

El artículo intenta ver la cuestión del "sufrimiento de los justos" bajo la perspectiva teológica del Libro de Job, al ver a Job en contraste con el Primer Hombre. Además, explora la posibilidad de entender a Job no solo como un typos de Cristo sino también

* Slightly different version of the text was presented at the Albertus Magnus Summer Programe 2018. Supported by GAJU 157/2016/H. 
como typos de la Santísima Madre de Dios. Además de los propios textos bíblicos, el ensayo está fuertemente influido por el pensamiento de Tomás de Aquino.

Palabras clave: Sufrimiento de los justos, Adán, Job, Cristo, Tehotokos, Tomás de Aquino.

The Book of Job sets in front of us the question of the 'suffering of the just'. Card. Robert Sarah in his last book 'The Power of Silence' connects - rightly this question with the question of evil and mentions that these two problems have been companions of man throughout the whole history and no one has found a complete answer. Nicholas Diat asks in the same book how God can be silent face to face to the immense suffering present in the world. Card. Sarah answers by citing a theologian Bernard Sesboüé. According to him, by asking this question we do not know what we ask, for the evil cannot be comprehended; the evil, according to him, is an irrationality par excellence, and therefore to look for a rational answer always means to look for a partial answer. ${ }^{1}$

The starting point of this paper is the Book of Job, who seems to be the Old Testament personification of incomprehensible, irrational suffering. St. Gregory the Great provided the Church with an extended commentary on the mystical sense of this book. ${ }^{2}$ St. Thomas Aquinas provided us with a commentary on the literal meaning of the very book, stating that the Moralia on Job of St. Gregory cannot be overcome. ${ }^{3}$ This paper does not aim at surpassing either of those commentaries. Rather, it tries to find some deeper meaning of the 'suffering of the just' in the theological perspective both of the Old and the New Testament. However, I fully acknowledge that a) the question of evil and suffering cannot be answered fully, b) that many important questions will not be treated or will be treated only superficially, and c) that I omit the extended philosophical discussion thereof, for if we accept that evil and suffering are beyond our reason, as Card. Sarah suggests, it follows that it is also beyond the possibilities of a mere philosophical questioning. Thus, philosophy alone can hardly find an appropriate answer. In this attempt to find another possible theological answer, 'however, I am afraid I might be found just multiplying words and tossing them around.' (Cf. Job 18:2)

1 Robert Sarah, The Power of Silence: Against the Dictatorship of Noise (San Francisco, CA: Ignatius Press, 2017), 145.

2 Gregory the Great, Moralia in Job, 3 vols., trad. James Bliss (Lexington, KY: Ex Fontibus Company, 2015).

3 Cf. Thomas Aquinas, Expositio super Job ad litteram, Prooemium. Corpus Thomisticum [online], consulted 7 July 2018, http://www.corpusthomisticum.org/cio00.html. 
There are several events from the story of Job that I would like to refer to while leaving other points out. I will omit the cycle of speeches between Job and his friends, although they are very interesting themselves. Rather, I will refer to the initial, introductory interview between God and satan, Job's fight with the suffering, lamenting his fate, and God's final rebuke. Job, like many other old testament personages can be seen as a typos, image of New Testament events. While his being a typos of Jesus suffering on the Cross is quite obvious, I think he can be seen as a typos of the Most Holy Mother of God as well. In what manner will be the subject of further exploration.

Both in the story of Job and in the life of Jesus, satan and his temptations play some crucial role. In the book of Job, satan asked God permission for the maltreatment of his servant and shortly after stroke Job. Even through the mediacy of his wife and his friends, satan tried to diverge Job from his obedience to God.

Jesus, the incarnate Word of God, was tempted first during His great lent in the desert. He was tempted by the promise of all the worldly goods if only $\mathrm{He}$ rejected the Final Good. ${ }^{4}$ Second, He was tempted by his closest friend, the one who accepted him as the Messiah ${ }^{5}$ and shortly afterwards tried to diverge Him from the Cross. ${ }^{6}$ Third, he was tempted in Gethsemane by fear; he was tempted to prefer His own will to the will of His Father, to save His life, to prefer Himself to the other, to forsake all of His own ministry, teaching and mission. ${ }^{7}$ For the last time He was tempted on the Cross: 'Save thy own self: if thou be the Son of God, come down from the cross.' (Mt 27:40)

The question of evil, suffering and temptation seems to disperse far and wide and yet there is a common theme, as I believe. To track it will take some time and effort and therefore I ask for patience for two other stories should be taken into account.

"Non serviam," uttered the evil one and turned against Almighty God, in his self-love rejected the Love. Melkor tuned his own unmelodious theme and was not to mend his ways and did not wish to sing in a perfect harmony with the other Valar according to the will of Illuvatar. ' 'Sanctus, Sanctus, Sanctus,' sing the heavenly choirs in front of the throne of the Most High thus praising His

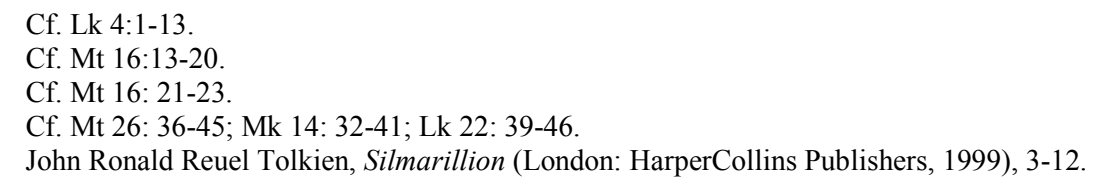


love and expressing their own, ${ }^{9}$ but alas, the first and most resplendent of God's creatures is missing.

The devil, being the highest among spiritual beings, was the most actual of created beings and as such was closest to the Absolutely Actual, Actus Purus, God Himself. ${ }^{10}$ By rejecting God, however, he fell and became the least actual of beings, thus becoming less then the lesser spiritual being, less than a man.

The Fall of Man and the corruption of the whole creation came subsequently. Whereas the non-intellective creation followed the Fall of Man somewhat automatically (and therefor it awaits the return of the sons of Man to their glory), ${ }^{11}$ the Fall of man did not follow satan's Fall automatically. This is shown in the scene of tempting Eve by delicious fruit.

Gregory of Nyssa in his book On Creation of $\mathrm{Man}^{12}$ sees Man to be the crown of creation; the one, to whom everything else in the created material world is subdued. This idea can be found also in the works of John the Damascene. Further, Thomas Aquinas sees in the whole scope of reality a hierarchy existing both in the immaterial (spiritual) world and in the material creation. On the highest rank stands, of course, God, who is. Below God there are immaterial, intelligent beings among whom there exist another kind of hierarchy, which is hardly to be described from the point of view of this life. The hierarchy among spiritual substances is dependent on the measure of their actuality and thus proximity to the Actus Purus. On the lowest rank of these spiritual substances, we can find a man, who belongs in here due to his intellectual soul. However, man also belongs to the material creation, due to his material body. As such, man stands on the highest rank among the material entities. ${ }^{13}$ Thus, if Man, the 'crown of creation', was due to his Fall lowered to the level of unintelligent beings (animals), it would have been unfitting should the lower creatures remain unaffected, just as it would have been unfitting should Man remain unaffected by the Fall of the Lucifer.

What is the difference between the case of Lucifer's Fall, Fall of Man and the automatic corruption of the material creation? The answer seems to be obvious. Man, unlike animals, plants or inanimate objects is endowed with an intellect capable of knowledge of the immaterial essences; will, mutually interconnected with the intellect; and ability to choose freely connected to both.

9 Cf. Is 6:3.

10 Cf. Thomas Aquinas, De Ente et Essentia, Corpus Thomisticum [online], consulted 26 Juny 2018, http://www.corpusthomisticum.org/oee.html.

11 Cf. Rom 8: 21-22.

12 Řehoř z Nyssy, O stvoření člověka (Praha: OIKOYMENH, 2013), 65-67.

13 Thomas Aquinas, De Ente et Essentia. 
If the Fall of Man was to follow the Fall of the Lucifer automatically, he would have been denied the free choice and thus, man would have not been able to use his powers of the soul (namely the intellect and the will). If man could not have made a use of his own intellect, will and exercise choice, he would have become a puppet in puppeteer's hand, instead of a child of the Almighty.

This is not the case with the lower organisms, which have never been endowed with the intellect, will and therefore a free choice in the first place. Although their automatic degradation caused some metaphysical disorder just as the Fall of the angel and the Fall of the Man (hence the 'corruption'), it did not cause any further disorder by depriving them of the exercise of their soul's powers. Due to the corruption, the creation does not exist to its fulness and original beauty. 'That nature in its turn will be set free from the tyranny of corruption, to share in the glorious freedom of God's sons. The whole of nature, as we know, groans in a common travail all the while.' (Rom 8:21-22)

'Non serviam', uttered the foremost of God's creatures and offered a treason to Woman. Like a man, the angel also has an intellect and the will and therefore a free choice. As R. Nutt mentions in connection to Thomas's Commentary on Job, God permitted Lucifer to tempt Eve. God did not order, nor did He hinder him, ${ }^{14}$ thus giving both to the devil and to the man a possibility to make a use of the powers of their souls and decide for themselves; both the angels and the men have been given a possibility to choose freely and ground such a choice in their knowledge of God..$^{15}$ In both stories, God did not order the temptation, nor did he prevent it thus giving the satan another chance to decide for himself whether he would or would not strike.

Eve was not pushed or determined to accept the temptation. She was given the choice to accept the Word of God and trust Him or to accept the word of the Fallen angel. Despite her knowledge of God (which was not identical with the knowledge of God in the beatific vision), ${ }^{16}$ she decided to yield to the temptation, to prefer the created beauty to the uncreated One. Adam had also the possibility to decide for himself, yet he accepted the offer of Eve without much hesitation. Thus, neither of them used their intellect appropriately but rather let the other to

14 Roger W. Nutt, "Providence, Wisdom, and the Jusice of Job's Afflictions: Considerations from Aquinas' Literal Exposition on Job", Heythrop Journal 56/1 (2011): 7.

15 Cf. Thomas Aquinas, Summa Theologiae I, q. 59; q. 63; ST IaIIae, q. 13. In the case of the evil angel, it is noteworthy that the choice made (to reject God and thus His Glory) was made once and for all. However, R. Nutt understands the question of choice of the devil in such a way, that God gave devil a possibility to act (to strike) or not to act (not to strike), not a choice to do Job good.

16 Cf. ST I., q. 94, a.1. 
decide what is or is not good. ${ }^{17}$ When God was walking in the garden of Eden in the silent breeze, Man put a blame on the Woman who put the blame on the Serpent. Both denying they made a free choice thus degrading themselves to the level of an unintelligent animals or worse - things. They showed lack of confidence in the merciful God, their Father and hoped God saw only their physical appearance as Simeon the New Theologian mentions:

"Since Adam was deceived he hoped that God would not know his sin. (...) While he was thinking these thoughts (...) God, unwilling to multiply his guilt, says, 'How did you realise that you are naked? Unless you ate of the tree of which I commanded you not to eat'. It is as though He said, 'Do you really think that you can hide from Me? Do I not know what you have done? Will you not say, 'I have sinned'? Say, O wretch, 'Yes, it is true, Master, I have transgressed Thy command, I have fallen by listening to the woman's counsel, I am greatly at fault for doing what she said and disobeying Thy word, have mercy upon me!' (...) For had he said this he might have stayed in paradise." 18

In the Canon of St. Andrew of Crete, we read a lament of Man's fate:

"My transgressions rival those of first created Adam, and because of my sins I find myself naked of God and of His everlasting kingdom. Alas, my wretched soul, why are you like Eve? For failing to observe just one of your commandments, O Saviour, Adam was justly exiled from Eden. Sensing his shame, Adam dressed himself in fig leaves, and like him I now wear a garment of shame which reveals my many passions. Through love of pleasure has my form become deformed and the beauty of my inward being has been ruined. $\mathrm{O}$ Saviour, I have defiled the garment of my flesh and polluted that which You fashioned within me according to Your own image and likeness. With passions have I darkened the beauty of my soul and permitted my whole inward being to become mire. I lie naked, having torn up the garment which my Creator fashioned for me in the beginning. I am ashamed, for the serpent deceived me and my garment is in tatter. I lie naked and ashamed, for the beauty of the tree, which I saw in the middle of the garden, deceived me. The demons have cut deep wounds of passion into my back; their lawlessness has made it like a plowed field. I offer you, O Saviour, sincere tears and the deepest groans of my

17 This seems to be the paradox of the account about the temptation in the Eden. Adam and Eve were free before the Fall to choose according to their knowledge and counsel received from God. Yet, in choosing to obey the counsel of a creature instead of the counsel of the Creator in pursuit of a freedom which satan promised them, they paradoxically lost what they already had and never gained what they were promised, for the one, who is creature himself, does not have power of the Creator.

18 Simeon the New Theologian, The Discourses, (Classics of Western Spirituality, NY: Paulist Press, 1980), 95. 
soul, crying from the heart, 'O God, I have sinned against You, be merciful to me.",19

The Book of Genesis shows quite clearly that the choice of Adam and the expulsion from the Paradise had immense consequences. Multitude of woes, sorrows and sufferings previously unknown, came upon the children of Man. Death was the most dreadful of them all.

In the Old Testament it is Job in whom the woes and sorrows of the human lot found their most striking expression - apart from the worst of them, the death. Though it seems Job would have prefered the death to the living hell of his afflictions. Job was said to be man just, following the prescriptions of God's law minutely, living in the fear of God, fear full of awe. After he was given everything, everything was taken from him in such a swift manner that plainly it must have been the will of God to deprive Job of every created good. ${ }^{20}$

There is the famous introductory part of the encounter between God and the devil. This part can shed a doubt on the assumption that God is good. God in the dialog with satan, the one who refused to serve, although he had been his foremost servant among the angels, points Job out as his special servant among men. Satan asked to be given a possibility to strike Job to show God that his most precious servant is no more than a mere opportunist. ${ }^{21}$

Job suffered and suffered much. Not only by the external afflictions that hit his household and his body but he also suffered by the disbelieve and discouragement both of his wife and his closest friends. His wife seemed to take side with the evil spirit, ${ }^{22}$ just as Eve had done, tempting Job even more. Job, unlike Adam before him, refused simply to follow the advice of his wife and made a use of his own knowledge of his Master. His friends boasted at their knowledge of God and His ways, giving well-meant advice totally rooted in a solely human point of view. ${ }^{23}$ They seemed to be incapable to transcend the human perspective and grasp what Job himself only foreboded, i.e. that he was a part of some higher, different episode which he himself could not grasp fully and in which he (perhaps) played only a minor role. Job in his self-justifying attempt to persuade his friends of the correctness of his own position, did not simply yielded to the arguments of the others. Although he could not express himself perfectly his speech often seems to be rooted in some other kind of knowledge of God,

19 Canon of St. Andrew of Crete. Orthodox Christian [online], consulted 7 July 2018, http://ww w.orthodoxchristian.info/pages/canon.htm.

20 Roger W. Nutt, "Providence, Wisdom, and the Jusice of Job's Afflictions", 7, citing Aquinas.

21 Job 1: 1-12; 2: 1-6.

22 Cf. Job 2:9.

23 Cf. The three cycles of speeches in the book of Job. 
perhaps a more intimate one than only the one borrowed and accepted from the tradition.

Job suffered and was ready to suffer whatever loss may come upon him due to the Lord's judgement, but he did not suffer perfectly. Although he knew what was just to do and was willing to do so, he was not ready to accept whatever affliction without murmur, fight, self-justification as is shown in the aforementioned attempt to persuade his friends about his case.

Yet, even in the depth of his despair he hoped. Never lost sight of the higher end, never really doubted God's Majesty and His justice, only cried for some kind of meaning, for justice for himself, for explanation that would help him understand. He was not ready to accept the suffering without understanding why. $\mathrm{He}$, the just man, was thirsty for justice and he mourned. Thus, he should be comforted and would have his fill as would have been promised. (Mt 5:5-6) Despite all his striving he accepted the will of God, was reconciled, remained faithful to his Lord until the happy end although he was not spared a rebuke.

The final end of man is, according to Aquinas, God himself, of course, but more precisely the final beatitude. ${ }^{24}$ This causes the rest of the will and incessant act of the intellect, the knowledge of God.$^{25}$ In Prima Secundae in the sequence of questions about the will, St. Thomas makes it clear that nothing but reaching this final end can satisfy the will and also that the satisfaction of the will goes hand in hand with an intensive delight experienced in the soul. ${ }^{26}$ Further, there are a few interesting questions not only about the choice, ${ }^{27}$ with an obvious connection to the will, but also about a counsel. Few points are quite interesting. The counsel is an inquiry based both in the will and in the intellect. Both angel's and man's intellect and will are created and as such limited. Thus, their counsels are always rooted only in an inquiry which is more or less accurate, more or less true. On the other hand, God's 'scientia' is the sure knowledge of all the effects without any reasoning process. Then it follows that His counsel bears a certainty of His knowledge and/or judgement. Thus, there is no place for inquiry. St. Thomas quotes John Damascene: 'God takes not counsel: those only take counsel who lack knowledge." St. Thomas further states that "those things which

24 Thomas Aquinas, ST, IaIIae, q. 3-6; ST I, q. 82, a. 1. The Leonine Edition available at Corpus Thomisticum [online]: corpusthomisticum.org, consulted 7 May 2018) is used. English translation used Thomas Aquinas, Summa Theologiae, Lander, Wyoming: The Aquinas Institute for the Study of Sacred Doctrine, 2012.

25 Ibid., a. 2; a.2, ad. 1-2.

26 Ibid., IaIIae, q. 3, Ibid., q. 4, a. 1, corp., a. 3, corp., a. 5, corp.

27 Ibid., IaIIae, q. 13. 
are most certainly good in the opinion of the wise and spiritual men are not certainly good in the opinion of many (carnal) men. ${ }^{28}$

Adam in the Paradise had some kind of natural knowledge of God and he received God's counsel (not to eat from that forbidden fruit). Moreover, Adam lived there in the state of blessedness. Yet alas, this blessedness was not enough for him. Instead of being satisfied with inner satisfaction, he turned his gaze from the Almighty and chose to listen to the counsel of the first robber who promised, Adam could rob God of his Throne. Thus, Adam received the counsel based on a mere inquiry and rejected the counsel based in certainty of absolute knowledge. He exchanged blessedness for non-blessedness. This exchange brought to the creation and to the progeny of Adam a lot of suffering.

Job who was called just and a servant, despite his immense sufferings, stayed as much faithful to God's Law, to God's counsels as was possible. He did not reject God bearing in mind that the loss of temporary goods is nothing in comparison to the uncreated Good. We can also mark that he refused the wellmeant counsels of other human beings, which were rooted solely in their own human intellect. He persevered in the hope of the eternal blessedness. 'For I know that my Redeemer liveth, and in the last day I shall rise out of the earth. And I shall be clothed again with my skin, and in my flesh I will see my God. Whom I myself shall see, and my eyes shall behold, and not another: this my hope is laid up in my bosom.' (Job 19:25)

When the Redeemer was to become clothed in skin to see God the Father in His flesh, an angel came to another servant of God. And she, once again without the stain of Adam's sin, was said to be only a humble girl of a humble origin. Unlike Job, she was not blessed by a lot of worldly goods. Yet, the angel

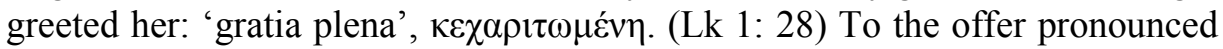
by the angel, she simply replied: 'Behold the handmaid of the Lord; be it done to me according to thy word.' (Lk 1:38) In a simple answer she announced her subordination and preparedness to accept whatever may befall her according to the will of God, acknowledging herself to be only a servant.

By her 'fiat' the humble girl did not receive the plenitude of created goods, but plenitude of uncreated goods; she did not receive the plenitude of things corruptible, but plenitude of things incorruptible, plenitude of what is. She received the Word of God, not only in her intellect as a counsel but in her very body as a child. Thus, the Word of God was not a mere commandment given to a servant, but the Word of God conceived in her flesh was the living reality, 
reality, which filled all her being. Instead of a relationship of servitude between God and his servant, the servant became Mother of God, thus entering a relationship of love; not only love of man towards his God but also the love of God towards man.

Mother of God, gratia plena, full of grace, the one who was given everything, for she could not have been given more, was blessed as much as a man can be in this life. She did not fully understand, yet in her encounter with Elisabeth, in her song of praise of God, she expressed blessing which would have been promised by her Son on the mountain later in life and by her very life she embodied each one of those blessings. ${ }^{29}$

'Blessed are the poor in spirit: for theirs is the kingdom of heaven. Blessed are the meek: for they shall possess the land. Blessed are they that mourn: for they shall be comforted. Blessed are they that hunger and thirst after justice: for they shall have their fill. Blessed are the merciful: for they shall obtain mercy. Blessed are the clean of heart: for they shall see God. Blessed are the peacemakers: for they shall be called children of God. Blessed are they that suffer persecution for justice' sake: for theirs is the kingdom of heaven.' (Mt 5)

The Mother of God, although blessed to the highest possible degree, was promised suffering soon after the birth of her Son. ${ }^{30}$ Yet, she had said her 'fiat' and never took it back. Thus, it was that even under the Cross, she wept and her sorrows were fulfilled to the uttermost depth but unlike Job she suffered silently, giving back to God what He had given her, being fully aware that she was but a dust. She did not murmur, nor did she try to justify her case. And yet, Job lost only temporary goods, only corruptible goods, but she, she lost the Word of God, plenitude of what is, the Life itself. She suffered the loss without a word for no Word was left to her; she, the 'gratia plena' became 'mater dolorosa', mother full of sorrows (fullness expressed by the number seven). No man could have suffered more for no man could have lost more. The most pure human being who have not sinned, who was conformed to the will of God absolutely, the one who was absolutely blessed, absolutely, unjustly suffered and remained silent. In her person just as in the person of her Son, true God and true Man, the absolute blessing and absolute suffering became one, showing us, perhaps, some deeper dimension of suffering itself. Facing the Crucifixion, bearing in mind Adam's Fall and Job's self-justifying cry, we could delve a bit further into this uncomprehensive mystery. 
In the events preceding the crucifixion, in the palace of Pontius Pilates, both the pharisees, the mob and Pontius Pilates himself were given several opportunities to make a choice. Pontius Pilates was warned by his very wife: Jesus was just. He tried to liberate him and yet, in the end, made a choice which he did not like. He succumbed himself to the judgement and the choice of pharisees, whom he should have governed, thus making himself their subject. Satan refused to serve, refused to be subjected to God and was lowered below the grade of an angel. Adam refused to obey God and was lowered below the grade of man. Adam threw away the consequences of his choice and the responsibility pointing to Eve, Pontius Pilates did the same thing by washing his hands. ${ }^{31}$ The Word of God incarnate accepted their free choice, remained silent until on the Cross and suffered by the hand of man.

When Mary, full of grace, encountered the angel, she recognised herself to be a handmaiden but through her unconditional and unqualified acceptance of the will of God she became the Mother of God. Christ during his ministry, despite his kingly Majesty, accepted the position of a servant when declaring: 'Even as the Son of man is not come to be ministered unto, but to minister, and to give his life a redemption for many.' (Mt 20:28).

Later on, when he was instructing his disciples, he said to them: 'You are my friends, if you do the things that I command you. I will not now call you servants: for the servant knoweth not what his lord doth. But I have called you friends: because all things whatsoever I have heard of my Father, I have made known to you.' (Jn 15:14-15)

Adam did the things that God had commanded him not to do and thus separated himself from the friendship and the love of God. Job did the things he was commanded to do but never knew what his Lord did. Mary did the things she was asked to do, accepted the Word of God, the Wisdom, and in becoming to know God, she ceased to be the handmaiden and became the Mother. Christ did the things of His Father being obedient even unto death on the Cross. Unlike in the case of Job, who was recognised by God to be his just servant, Christ was recognised by God as his beloved Son. Although proclaiming he had come to serve, Christ never recognised himself to be a servant - for he did the things of God while having the knowledge of God's doings. He brought this knowledge of the Father to man and gave man everything he knew; gave man a chance to gain knowledge of God not only through his ministry but in his very person. They could see Him, feel Him, touch Him, know him through their very own sensual experience. And $\mathrm{He}$ called them friends and promised them they should 
have share in his chalice (Mt 20:23). He called them friends, i.e. those who do the will of God and know it, and promised them the suffering. It seems that to be a friend of God goes hand in hand with the suffering. To be a friend means to love the other. Thus, to follow God's will means to love God and this leads to suffering.

Christ, the suffering Redeemer, proclaimed he had not come to destroy the law but to fulfil it. (Mt 5:17). And when he was asked, what the greatest commandment was, He replied: 'Thou shalt love the Lord thy God with thy whole heart, and with thy whole soul, and with thy whole mind. This is the greatest and the first commandment. And the second is like to this: Thou shalt love thy neighbour as thyself. On these two commandments dependeth the whole law and the prophets.' (Mt 22: 37-40) If He came to fulfil the law, it means He came to fulfil these two commandments - the love to God and the love to man. He fulfilled the commandment to love God by being obedient to the will of God even unto the death on the Cross and he fulfilled his love towards man by accepting the Cross from the man. He showed in His very body and suffering what it means to love the enemies, to show them the second cheek, to give them doubly what they asked for. They asked not for his coat but for His life and He laid His life into their hands and by giving men His life he brought them Life eternal thus giving twice what was asked of him. The possibility to live the life on this Earth in the friendship with God and the promise of life without end, if only man persevered in this friendship.

He offers to share with man everything both in this life and also in the life to come. Not only can we see the fulfilment of both promises in the life of Theotokos, but also in the parable of the prodigal son. The father's answer to the envious older brother at the end of the story is most instructive. Father's answer suggests that to be with the father is more than anything else. To stay in the loving home is more pleasurable, than to go abroad. To be with the Father always is the root of happiness of man, for the loving relationship with living father is something higher than the ephemeral enjoyment of lifeless things.

On the Cross the God-became-man, Love incarnate, suffered and His Mother, who in one simple 'fiat' had accepted everything from the hand of God, suffered with Him and in their joined suffering for the same Love, the redemption of man was completed. Mary by her share in her Son's suffering became co-redemptress, mediatrix. In Mary under the Cross and Jesus on the Cross the mystery of suffering became the mystery of Love between God and Man; mystery, which was hidden in the Book of Job, was made visible. 
On the Cross, the drama of human suffering was explicitly shown and more so. If it was only the human suffering, the whole episode would have been somewhat pitiable. But alas, it was never only the man who suffered but God was present in his suffering, as was shown in the person of God-man, Jesus Christ. Christ on the Cross showed us, that from the beginning, whatever man suffered, God was present amids his sufferings. God, who is in everything by His presence, power and grace ${ }^{32}$ accepted the rejection of His grace, one mode of his indwelling in the creation. His grace has been rejected first by the evil one and afterwards by Adam. God, Love itself, whose grace was rejected, did not, however, ceased to be present in His creation by His presence and power.

Satan has not been deprived of his free choice. He has been given a choice to serve God, be God's messenger, help God in governing his creation, help man as his brother despite the fact that man stands on a lesser degree as is repeated in the Canon of St Andrew of Crete. Satan has rejected to serve, has rejected to follow God's will and thus has rejected grace and love. He wants to be God's friend no more. He has deprived himself of everything God's, but he couldn't have deprived himself of the very act of being which is from God. And God has been suffering in him his emptiness. Satan could have made a choice and he has chosen to harm God's creation.

Adam was given a free choice and he preferred the empty words of Satan to the Word of God, the fulness of Love. Adam's decision has harmed the creation and has brought into the world all the woes imaginable. Adam suffered for his loss and God suffered in him. Like Job later on, Adam the penitent awaited his Redeemer.

In the story of Job, Satan was again offered the choice to harm or not to harm. He chose to have his will with Job. God, being present in the suffering Job, suffered all the trials with him. In the end he rebuked his servant for his unwise speech. Job should have known better, Job should have known God was present in his sufferings all the time.

In Christ and His passion God's thirst for Love has been satisfied, just as in Mater dolorossa. The suffering introduced by harm, disobedience, loss of love has been overcome by love serving unto death, accepting anything that befell Him and Her silently, never striking back so that no more harm would be done. Non-love, harm, merciless governing, enmity resulting in the suffering of other beings on the one hand have been overcome by suffering for the sake of uncondi-tional love, servitude and friendship on the other. 
'Love your neighbours'33, 'Love your enemies', 'Do to your neighbours as you wish it was done unto you' ${ }^{34}$ has become the chalice of Eternal Life. The suffering which has been the result of intelligent being's choice of departure from the grace of God has thus become the tool of redemption of man; of his return to the all loving embrace of God, of gaining the fulness of God's grace again. Suffering without murmur, without striking back and causing more harm, has become the way of Love, a way to become again the children of God.

\section{REFERENCES}

Canon of St. Andrew of Crete. Orthodox Christian [online]. Consulted 7 July 2018, http://www.orthodoxchristian.info/pages/canon.htm.

Gregory the Great. Moralia in Job. 3 vols. Traduction James Bliss. Lexington, KY: Ex Fontibus Company, 2015.

Nyssy, Řehoř z. O stvoření človéka. Praha: OIKOYMENH, 2013.

Roger W. Nutt. "Providence, Wisdom, and the Jusice of Job's Afflictions: Considerations from Aquinas' Literal Exposition on Job." Heythrop Journal 56/1 (2011): 1-23.

Sarah, Robert. The Power of Silence: Against the Dictatorship of Noise. San Francisco, CA: Ignatius Press, 2017.

Simeon the New Theologian. The Discourses. Classics of Western Spirituality, NY: Paulist Press, 1980.

Thomas Aquinas. De Ente et Essentia, Corpus Thomisticum [online], consulted 26 Juny 2018, http://www.corpusthomisticum.org/oee.html.

-. Expositio super Job ad litteram, Prooemium. Corpus Thomisticum [online]. Consulted 7 July 2018, http://www.corpusthomisticum.org/cio00.html.

-. Summa Theologiae, Lander, Wyoming: The Aquinas Institute for the Study of Sacred Doctrine, 2012.

Tolkien, John Ronald Reuel. Silmarillion. London: HarperCollins Publishers, 1999.

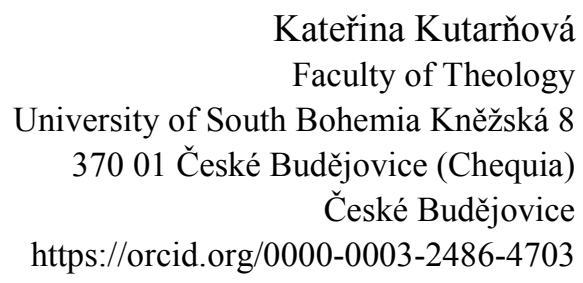

